Revue de recherche interdisciplinaire sur le genre et la sexualité

35 | 2018

Striges en tous genres

\title{
A Place Where Nobody Has Ever Been. In Search of Heimat in Lamrabet's Vrouwland and El Bezaz' De verstotene
}

Jossfinn Bohn

\section{OpenEdition}

\section{Electronic version}

URL: https://journals.openedition.org/sextant/363

DOI: $10.4000 /$ sextant.363

ISSN: 2795-8736

\section{Publisher}

Éditions de l'Université de Bruxelles

\section{Printed version}

Date of publication: 1 December 2018

Number of pages: 11-22

ISBN: 978-2-8004-1636-6

ISSN: 1370-267X

\section{Electronic reference}

Jossfinn Bohn, "A Place Where Nobody Has Ever Been. In Search of Heimat in Lamrabet's Vrouwland and El Bezaz' De verstotene", Sextant [Online], 35 | 2018, Online since 01 November 2021, connection on 08 December 2021. URL: http://journals.openedition.org/sextant/363 ; DOI: https://doi.org/ $10.4000 /$ sextant.363

\section{(c) (i) (2) (2)}

La revue Sextant est mise à disposition selon les termes de la Licence Creative Commons Attribution Pas d'Utilisation Commerciale - Partage dans les Mêmes Conditions 4.0 International. 


\title{
A Place Where Nobody Has Ever Been. In Search of Heimat in Lamrabet's Vrouwland and El Bezaz' De verstotene
}

\author{
Jossfinn BOHN
}

At the core of the broader context of this article - a doctoral thesis - lies the study of the literary category feminine literature of immigration, supported by the theoretical concept of literary categorization in general. The project focuses on the analysis of a selection of literary works that deal - directly or indirectly - with the topic of immigration and which are written in Dutch by female authors with an immigration background. Its main objective is to answer the question about the pertinence - or lack of pertinence - of a literary category of feminine literature of immigration and the thereby related advantages and disadvantages of literary categorization. Related to this goal is the wish to offer a critical and as complete as possible evaluation of the literary category of feminine literature of immigration and of the concept of categorization in general.

The present article takes up an element of the second part of the doctoral study, that is devoted to a comparative literary study, which lays the focus on feminine literature of immigration. This category, to this day unrecognized, provides a fertile field of exploration and gets submitted to the following two central questions: How are the concepts of identity quest ${ }^{1}$, uprooting, in-betweenness ${ }^{2}$, and Heimat handled in the respective works ${ }^{3}$ ? And how are the so-called feminine concepts such as

1 See e.g. H. LouwERSE, “Zwartrijders in de Nederlandse literatuur: het motief van de queeste in de migrantenliteratuur", in G. ELSHOUT et al. (ed.), Perspectieven voor de internationale neerlandistiek in de $21^{e}$ eeuw. Handelingen Veertiende Colloquium Neerlandicum, Woubrugge, IVN, 2001, p. 169-178.

2 See e.g. S. Moslund, Migration, Literature and Hybridity. The Different Speeds of Transcultural Change, Basingstoke, Palgrave Macmillan, 2010.

3 See e.g. M. Preglau, “"'Ethnizität”, "Klasse/Schicht” und "Gender” als Kategorien der Migrations- und Integrationsforschung", in H. MitTerbauer et al. (ed.), Moderne. 
maternity and marriage, as well as the view of the patriarchal society and the subjectobject relationship between men and women ${ }^{4}$ treated ${ }^{5}$ ? These key questions, which are bound to more specific ones, will help to investigate and pin down how these concepts are handled in the literary works of the corpus of the thesis and thereby help define the feminine literature of immigration.

The following article presents one of the very first elements of the literary analysis of the study. It therefore features one of the key notions to the research: Heimat. As the subtitle of the article suggests, the reader is invited on a search of this concept in two novels that are part of the study's corpus. These are Vrouwland ${ }^{6}$ by Rachida Lamrabet and De verstotene 7 by Naima El Bezaz. Before getting to the heart of the matter, it seems useful to have a closer look at the terminology of Heimat. Since there does not seem to exist an appropriate translation of the German term that would contain the same intricate meaning and different subtle connotations of it, Heimat became the name of a whole concept. However, in contrast to expectations of a univocal meaning, opinions about the concept's true meaning are strongly diverging. Proof for these varying understandings are for example the dictionary entries for the term. One finds such small definitions as "home (land/country) and birthplace" that are mainly limited to a geographical place, but there exist more complex definitions too. One example is the definition from Der Brockhaus in einem Band: "a place or landscape, which the human being is born into and through which among other factors his/her identity, mindset et al. are shaped" 8 . One can argue that the terms place and landscape are not limited to their literal meaning but also understood on a figurative level, meaning a mental, inner place/landscape. When adding this second layer of meaning together with notions as identity and mindset, the complexity of the concept becomes even more visible.

Since Heimat represents one of the key concepts of the study, it is thought important to clearly state the presupposed meaning of the term. To do justice to the multi-layered dimension of the term Heimat, it is in the following understood as a geographical, topological place/landscape, a birthplace, and at the same time as an inner, mental place/landscape of belonging - of feeling at home -, so to speak at the same time a physical and mental Heimat. Both places exert a strong influence on a human being's shaping of identity and mindset and are related to the social and cultural contacts for example religion - that exist in these places. One of the reasons for this choice of meaning is the wish to get as close as possible to the complexity of the term without excluding possible other meanings of it. Therefore, and with the formability of the concept in mind, this definition is in no way considered to be complete. This said fluidity can also be perceived, when reading such seemingly diverging definitions of

Kulturwissenschaftliches Jahrbuch Migration, Innsbruck, Studienverlag, 2008, p. 92-103.

${ }^{4}$ See e.g. I. StePhan, Musen \& Medusen. Mythos und Geschlecht in der Literatur des 20. Jahrhunderts, Köln/Weimar/Wien, Böhlau, 1997 (Literatur - Kultur - Geschlecht 9).

${ }^{5}$ See e.g. for gender-oriented narratology, V. NüNNING et A. NüNNING, Erzähltextanalyse und Gender Studies, Stuttgart/Weimar, J. B. Metzler, 2004.

${ }^{6}$ R. LAMrabet, Vrouwland, Wommelgem, Van In, 2012.

7 N. El Bezaz, De verstotene, Malmberg, Den Bosch, 2007.

${ }^{8}$ Own translation; "Heimat", Der Brockhaus in einem Band, 13th ed., 2009. 
Heimat as from German philosopher Ernst Bloch and Stanford professor of literature Hans Ulrich Gumbrecht. While Bloch sees it as a distant place of longing, a place, where nobody has ever been ${ }^{9}$, Gumbrecht describes it as following: "Heimat is (...) not more (and not less) than the wish to nestle against somebody (...) in a psychological and a physiological way" ${ }^{10}$. Even though, these two men seem to talk about different things, the complexity of the Heimat concept allows to unite these statements.

In the spirit of the study, the nexus Heimat and migration appears rather obvious. When reading a standard definition of migration, such as "migrate: to travel so as to change one's place of living, especially for a limited period: [e.g.] Some tribes migrate with their cattle in search of grass" 11 or "sociology: walk of individuals or groups in a geographical space, e.g. guest workers, also in a social framework" ${ }^{12}$, one - who is familiar with the Heimat concept - could immediately ask the question about the implications that such a wandering - since this is the meaning of the Latin verb migrare - and implied lack of stability have on the concerned individuals' handling of Heimat. In order to make the following literary analysis more easy to follow, some insights are offered into other concepts that are inextricably bound to the here dominant couple Heimat - migration.

One concept that should not be neglected is the one of fatherland that is often presented as opposed to the host country and synonymous with country of birth and home country. In order to get a clear understanding of these terms, one should keep in mind the multi-layered definition of Heimat, which does not only suggest a geographical dimension but a psychological as well. This complexity of meaning can also be found in such concepts as fatherland, which are generally only associated with a well-defined geographical place. However, the following comparative literary analysis will show a number of different forms and dimensions these concepts can take. For example, the fatherland is not necessarily limited to one's country of birth or its patriotic connotation. It can take the far more abstract and personal dimension of a space uniting one's own or family's and/or cultural grouping's heritage and memories. Following this logic, one's fatherland does not have to be synonymous with one's country of birth. In this same vein, one's home country/land can be understood from a very personal angle, defined by the individual's feelings and concept of Heimat.

The comparative literary analysis of Vrouwland and De verstotene in this article focuses on the concept of Heimat. It is crucial to point out that in this context, the term comparative receives a double meaning. First, the article aims to compare two novels and their protagonists' handling and struggling with the concept of Heimat in order to reveal the complexity of it. Second, the adjective comparative stands for the two axes between which the analysis and the novels' characters are torn. These poles appear in different shapes and are situated on a continuum whose two end points are abstract

9 See E. Bloch, Das Prinzip Hoffnung. Kapitel 43-45, Frankfurt a.M., Suhrkamp, 1985, p. 1628.

${ }^{10}$ Own translation; H. U. Gumbrecht, "Gibt es noch, Heimat?", FAZ Blog - Digital/ Pausen, 28 February 2013, http://blogs.faz.net/digital/2013/02/28/gibt-es-noch-heimat-150/. Accessed 23 February 2018.

11 "migrate", Longman: English Language and Culture, 3rd ed./2nd impr., 2006.

12 Own translation; "Migration", Der Brockhaus in einem Band, 13th ed., 2009. 
and concrete. Some examples of these axes are here vs. there, now vs. then and home country vs. host country. By explaining the terminology, it becomes visible for the reader that there is no such thing as a simple dichotomy between the different concepts but rather a complexity, which is linked to the concept of Heimat.

When reading the two novels, one text excerpt in Vrouwland and the motto of De verstotene can act as a figurative door opener for more profound reflections about Heimat.

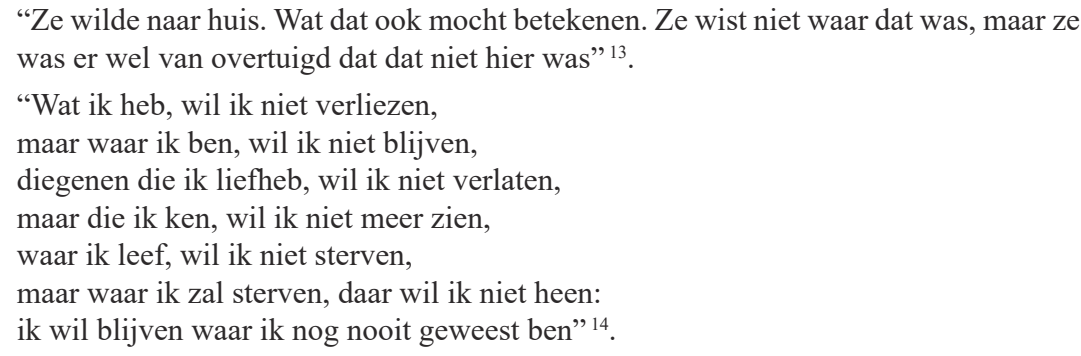

To be able to carry out the analysis of the handling of Heimat by the novels' protagonists, an outlay of their general situation is needed. Mina, the main character in De verstotene, is a young Dutch-Moroccan woman living in Amsterdam. One of Vrouwland's protagonists is Mariam whose parents have immigrated to Antwerp, where they gave birth to their daughter. Both women were born in Europe and even though none of them has experienced migration, it is intrinsically part of their identity. Mina and Mariam have distanced themselves from their families and turned their backs to the associated cultural background. One sign for this avoidance of their Moroccan heritage, longing for a Western life and attempt to pass as white, is their deliberate change of name. Mina chooses the name Amelie in order to appear more European and Mariam has the same intentions when naming herself Mara. By transforming their names, they hope to get rid of the otherness associated with their original names. A second reason for this choice may be the wish for security and possibility to fuse together with the mass.

Given this situation, one may ask what exactly represents the concept Heimat for these two women. In the beginning of both novels, the women's wish to be(come) members of the Western society is almost tangible. Besides their changing of names, Mariam and Mina choose a European partner. However, it seems symbolic that both relationships come to a negative end. There is one episode in Vrouwland, which makes the cultural barriers between Mariam and her boyfriend Peter's background outstandingly obvious. Mariam and Peter visit his parents and his mother asks Mariam questions strictly related to her Moroccan and Muslim background. Mariam cannot hide from Peter the fact that she is upset about his mother's behaviour and utters the following sentence fraught with meaning: "Ik ben het kotsbeu telkens aan mijn afkomst herinnerd te worden, ik haat het herleid te worden tot een etnie, een

\footnotetext{
13 R. Lamrabet, Vrouwland, op. cit., p. 220.

14 T. Brasch in: N. El Bezaz, De verstotene, op. cit., p. 4.
} 
godsdienst of een kleur! Ik ben meer dan dat!" ${ }^{15}$. This utterance makes the unbreakable link between identity (quest) and Heimat clear. Since the study of the identity (quest) concept would outgrow the article's capacity, its study is limited to its relation to the Heimat concept. The text excerpt reveals the complexity of belonging and therefore associated with Heimat - especially for people with a migration background.

First, the analysis focuses on the term godsdienst, which means religion. Mariam comes from a conventional Muslim family, whereas Mina's religious background is more complex. Her Moroccan father is a moderate Muslim, but when he takes his niece as second wife, his European wife - Mina's mother - transforms into a radical Islamist and succeeds in dragging Mina's younger sister with her. As stated in the introductory part of the article, religion can be one of the factors related to the shaping of one's personal Heimat. For this reason, it seems useful to analyze the protagonists' bond with Islam and the attached social and cultural background. As far as Mariam is concerned, she always felt suffocated and summarizes the lack of choice as following: "Alleen mijn ouders en mijn godsdienst heb ik niet zelf gekozen en mijn vruchteloze pogingen om hen definitief uit mijn geheugen te wissen heb ik ondertussen gestaakt" ${ }^{16}$. With this utterance, Mariam points out factors which define in part her identity and which are out of her control, while she sees at the same time the impossibility of escaping these influences. This lack of choice drives Mariam towards a radical denial of her former background.

This powerlessness appears in another disguise in De verstotene. As a youngster, Mina writes down all her critical thoughts about Islam and the associated way of life. In school, one of her classmates - Rachid - gets hold of her writings and tries to rape her ${ }^{17}$. Thanks to her father's good name in the community, Mina is saved by other boys. Though, to prove his dominance, Rachid makes Mina's written thoughts public and initiates her downfall. The fact that Mina is threatened, saved and betrayed by men shows the patriarchal structure of her community and the relationship of power linked to it. The gendered aspect of this relation is also discernible in Vrouwland. One example is the following episode: During her childhood, Mariam and her family visit on several occasions their relatives in Morocco. During these trips, there are always the same constellations in the car: “(...) zij en haar zussen [kibbelden] over the zitplaatsen achterin. Voorin, naast de chauffeur zaten, zonder discussie of overleg, haar broer en moeder. Ze hadden weleens dit verschil in behandeling aangekaart, maar hun moeder makkte hun met heel weinig woorden duidelijk dat dit nu eenmaal de natuurlijke ordening der dingen was" ${ }^{18}$.

This hierarchical structure is one of the reasons making Mina and Mariam long for another Heimat. When abstracting this organization of community, the categorizing character-here in terms of gender - rises to the surface. The simple dichotomy between female and male determines one's range of control and possibilities concerning an entire life. Both female characters hope to find a more egalitarian version of society

\footnotetext{
15 R. LAMrabeT, op. cit., p. 120.

16 R. LAMRABET, op. cit., p. 83.

17 N. El Bezaz, op. cit., p. 206.

18 R. Lamrabet, op. cit., p. 87.
} 
in the Western lifestyle that would enable them to take control of their lives and experience the freedom they have always been searching for. The realization of these hopes could at the same time mean a further step in their search for Heimat, since this concept also has to do with a feeling of security and protection, or as Gumbrecht would put it: a space associated with the wish to nestle against somebody - something the female characters lack in their original surroundings.

The reader follows Mina and Mariam on their path from one supposedly unheimatlich social and cultural surrounding to the mythical ideal Western society as new Heimat. This journey - and the study of it - is symbolic in revealing the complexity of the Heimat concept in relation to migration and identity. First, the focus lies on the gender aspect on both sides. The patriarchal structure of the characters' Muslim community was already put forward and identified as one aspect alienating Mina and Mariam from their initial Heimat. In the same logic, one could inquire about the implications on the male characters' concept of Heimat in this phallogocentric structuring of community - making them the main subjects. The example of Mariam's brother Marwan comes immediately to mind. When following the same logic resulting in the female characters' denial of the social and cultural background, one would assume just the opposite for the male characters. However, Marwan does not at once prosper in this male assuring environment. Instead, he gets lost in the temptations of the Western world and seems to only regain his self-confidence and purpose when travelling to Morocco and emerging himself into the old Arabic writings of astronomy. The case of Marwan shows the difficulty - especially for individuals with a migration background - to get hold of a stable Heimat without succumbing to the in-betweenness of two utterly differing worlds.

Second, the gender relations surrounding Mina and Mariam in modern day Amsterdam and Antwerp and their handling and understanding of these are observed. Their choices for Belgian and Dutch boyfriends were already mentioned and now Mina's and Mariam's judgement of their partner and relationship are analysed. Especially in De verstotene, the reader gets already early on an idea of Mina's judgement about her boyfriend Mart's behaviour: "Het duurde lang, veel te lang. Ik was al minstens een uur klaar met douchen, aankleden en me opmaken. Mart daarentegen had door zijn ijdelheid de badkamer tot tweede slaapkamer getransformeerd; een plek waar hij in alle rust kon doen en laten wat hij wilde" ${ }^{19}$. And this is just the beginning of Mina's critical attitude towards Mart's manliness - or rather lack of manliness as she sees it. Mart, on his side, criticizes Mina's hardness and emotionlessness. As a conclusion, they separate and Mart enters a relationship with a more 'female' woman. As for Mina, she dives into a world of sex, a decision thanks to which she hopes to reach the ultimate sense of freedom and liberation she is so desperately yearning for. However, in this sensual environment, Mina does not fall for homosexuality - as experienced with her work colleague Esther - or another form of sexuality challenging the heterosexual norm and the associated gender roles. Instead, she seeks traditional masculinity and finds it embodied in Samuel, a Jewish playboy who reduces Mina to a sexual object. She gets pregnant by him and he rejects her and the unborn child.

\footnotetext{
19 N. El Bezaz, op. cit., p. 13.
} 
Eventually, the reader gets the impression of a self-chosen vicious circle by Mina. She flees the patriarchal structure of her community only to find herself again in a situation where she takes the subordinated role and receives disrespect from men. One may ask, if her self-hatred and lack of self-respect make her choose a Jewish man - considering the difficult relationship between Jews and Muslims.

Thanks to this first attempt of studying gender roles in both worlds of the novels, a first illustration of the inherent complexity of the two poles of Mina's and Mariam's journey was given. The Western society does not offer a positive counterpart to the world they are fleeing from. Instead, the characters find themselves in the same constellations of gender roles that they wanted to escape. The issue of gender can be one of the aspects shaping one's Heimat in terms of feeling at home in a certain constellation of gender roles and accepting or respecting of oneself in these. On the one hand, Mina unconsciously seeks masculinity in the Western society as a surrogate for the old order of her original community where manliness reigns. On the other hand, she and Mariam are looking for a haven in Western society for their status as women. The aspect of gender and the related roles make the in-betweenness clear, in which both women live. Even though, they break radically with their original surrounding, they are not capable of getting hold of a new and uniform Heimat in Western society.

Another aspect that can have an impact of one's shaping of identity is etnie or huidkleur - as to speak ethnicity and colour of skin. There is especially one episode in Vrouwland, which makes this issue visible. Mariam comes back from a business trip in the United Kingdom and lands at Brussels Airport. She is accompanied by a British lawyer - Shirley - who has a Nigerian background. To leave the airport, there are two exits: One for EUers and one for "de rest van de wereld" ${ }^{20}$. Mariam approaches with naturalness the exit for members of the European Union, but the two women are guided by a member of the airport to the other exit. Mariam is outraged, but Shirley says to her: "Come on girl, isn't it wonderful to have so many options?" ${ }^{21}$. In contrast to Mina and Mariam who desperately try to pass as white ${ }^{22}$, Shirley underlines the advantages of a multi-layered identity, allowing individuals to choose out of a broad spectrum of possibilities to shape one's lifestyle and ideology. Mariam on the other hand, is unable to see the positive aspects of a patchwork identity - associated with a similar Heimat. In her and Mina's mind, one has to make a radical choice in order to reach the Western paradise, the haven of security and peace of mind. Their changing of names is a first step on this path to the supposed goal. Yet, the issues of skin colour and ethnicity are not as easily transformable as names: "Ze was niet blank, en dat was tot nader order nog steeds het sterkste criterium om voor een Europese door te gaan. (...) Daar in de spiegel keek Mariam Lamkaddem haar triomfantelijk aan. 'Ik kleef op je huid, Mara"" ${ }^{23}$.

By introducing the character of Shirley, Lamrabet makes the reader aware of the different perspectives possible to adopt when being positioned between two realities.

\footnotetext{
${ }^{20}$ R. LAMrABET, op. cit., p. 119

21 Ibid.

22 See p. 14 changing of name.

23 Ibid., p. 118.
} 
In contrast to the other characters depicted in the novel, Shirley does not opt or long for one well-defined version of reality, but puts forward the image of a diversified world in which individuals are free to choose the composition of their identity and associated Heimat. In this logic, by being classified as non-European, Shirley does not feel alienated as Mariam does. Instead, she feels at home in both worlds and does not consider them as mutually exclusive.

Until now, the study of rather universal aspects shaping the Heimat concept led to concrete illustrations having their place in interpersonal relations. Therefore, these are further examined. This part of the study especially relates to Gumbrecht's idea of Heimat as being the wish to nestle against somebody. In order to attain a better understanding of Mina's and Mariam's decision to leave their social environment in search of a better Heimat, their childhood and adolescence should be investigated.

As mentioned before, Mina was raised by a European mother, who - in reaction to her husband taking a second wife - transformed into a radical believer and by a father being more absent than present. In particular, the mother image is worth looking in. Already on the second page of the novel, the reader gets an idea about the protagonist's feelings towards her mother. Mina browses through a photo album and finds pictures preceding her mother's religious transformation. Mina's description is the following: "Zij ligt languit en draagt een ultrakort jurkje. Ze ziet eruit als een model. Niets aan haar oogt moederlijk" ${ }^{24}$. This coldness, Mina's mother emits, lays the foundation for her daughter's feeling of forlornness. Furthermore, this utterance makes clear that the mother's religious transformation cannot be blamed for her personality, which was already before unmotherly. So even though, one could consider Mina's mother's external transformation from a beautiful blond model into a dark hidden figure as symbolic, her inner personality does not change as much as supposed, it rather gets hardened. The impact of this hardening is also perceivable in the place that Mina calls home. With her mother's turn towards radical belief, Mina feels that her home loses all possible happiness. An impression that is supported by such changes in the household as the radio's use limited to emitting the voice of a radical imam and the interdiction of any books other than the Quran and related writings.

Mina later summarizes the relationship to her mother as following: "Ik kwam weliswaar uit haar, maar volgens mij heb ik noot [sic] enige liefde voor haar gevoeld. Een kind leert van haar moeder, dus wat zij mij niet meegaf, kon ik ook niet met haar delen. $\mathrm{Zij}$ symboliseerde voor mij niet meer dan angst en onbegrip. Het was Sanaa die me leerde liefhebben. En later Saloua" ${ }^{25}$. This feeling of belonging - of Heimat -, the wish to nestle against somebody, that Mina misses with her mother, is temporarily found in her younger sister and her father's second wife - Saloua - who possesses a natural warmth. She is the very counterpart to Mina's mother and holds all the warmth Mina's mother is lacking and acts as an Ersatz mother. Sanaa shares a lot of characteristics with her stepmother: She is a patient girl who can express her feelings and who owns a certain calm that both Mina and her mother lack. In these two people Mina thus finds the love and safety she misses.

\footnotetext{
${ }^{24}$ N. El Bezaz, op. cit., p. 6.

${ }_{25}$ Ibid., p. 203-204.
} 
This feeling of belonging is complemented by the fact that Saloua and Mina's father are moderate believers and do not perceive the Western world as an enemy. When Mina is at their house, she drinks Coca Cola - one of the very symbols of consumerist Western society - and watches TV; things that do not exist at her mother's house and whose absence adds to the feeling of harshness. Another attempt to feel more at home in her given environment can be perceived in Mina's critical engagement with Islam. She writes down her thoughts and questions about the system of belief, which presents itself to Mina as an enigma. However, this attempt is not crowned with success but brought to an abrupt stop when Rachid makes her critical thoughts about Islam public, which results in Mina's repudiation by her father and mother. As a result, Mina, now De verstotene - the outcast - gets once and for all deprived of the feeling of Heimat she had found in Saloua and Sanaa, since Saloua remains loyal to her husband and Sanaa to her mother.

Given this context, Mina's search for a new Heimat and her choice related to it can be understood more easily. In contrast to the hostile environment she experienced at her mother's house, Saloua's place felt like a shelter. The positive feeling Mina associates with this place is also transmitted on the elements that are part of it. In this logic, Mina's choice for the Western world gets further explained, since the aforementioned elements of this world - like Coca Cola and the TV - convey a positive meaning for Mina and suggest that the world they belong to offer similar promising feelings.

A look into Mariam's past reveals a subtler picture. Everything begins with her name giving. Her parents do not choose her name but her older brother - the first child - Marwan does. From Mariam's perspective, her parents are so disappointed by the birth of another daughter that they do not even make the effort to name her but leave this task to their son. This interpretation - even though false - sets the tone for Mariam's outlook on her community. Another aspect of her childhood that considerably shaped Mariam's emotional life are the summer vacations in Morocco. Mariam calls them "zomer[s] van haat" ${ }^{26}$ and feels trapped during these periods: "Mara haatte het stoffige dorp. Ze haatte de constante bezoekersstroom die zich van de eerste tot de laatste dag bij hen andiende" ${ }^{27}$. This "collective belonging" ${ }^{28}$ or identity - in this case family does not represent a "refuge for Heimat" ${ }^{29}$ for Mariam, but instead generates a feeling of being trapped. The fatherland she gets to know on these occasions does not foster feelings of rootedness or belonging but stresses Mariam's urge for freedom.

This impression gets enforced by the family's expectations that rise with Mariam's age. She feels that she needs to play a role: "Wist zij veel dat ze eigenlijk niets meer en niets minder was dan weer een personage dat binnenkort zou aantreden in een tragikomedie die al sinds mensengeheugenis gespeeld werd" ${ }^{30}$. It is the traditional

26 R. LAMrABET, op. cit., p. 88.

27 Ibid., p. 89.

28 Own translation; V. VORDERMAYER, Identitätsfalle oder Weltbürgertum? Zur praktischen Grundlegung der Migranten-Identität, Wiesbaden, vs - Verlag für Sozialwissenschaften, 2012, p. 29.

${ }^{29}$ Own translation; Ibid., p. 27.

${ }^{30}$ R. LAMRABET, op. cit., p. 91. 
role that awaits women, implying marriage and children. Similar expectations come from Mina's mother, who wants her daughter to marry an older man from her mosque.

In the same traditional gender context, one can discern the binary categorization of women in the novels. One illustration is the comparison between Mariam and her school-day friend Najla. As young girls, they share a plan to become independent and strong women. But when they grow older and Mariam plans to leave the community, Najla has only incomprehension for her and names her egoistic. In contrast to Mariam, who opts for a self-determined life, Najla remains inside the community she has always known and fulfils the expectations linked to it: "Najla bleef en werd zo het toonbeeld van fatsoen, en beantwoordde aan de verwachtingen. Ze trouwde met een goede jongen uit de buurt, gaf een groots trouwfeest. Iedereen was uitgenodigd" ${ }^{31}$. Thanks to this behaviour, Najla becomes a role model of her community, whereas Mariam is seen as the unfaithful leaver. In terms of women imagoes, it can be summarized to Najla being the angel and Mariam "[de] gevallen vrouw" 32 - the whore. Another illustration of this constellation can be found in De verstotene. Salaa joins her mother in her radical beliefs and follows the path set out by her surroundings. As Najla, she gets married to an appropriate man and has children, while Mina acquires the reputation of an unbeliever who interferes with men. Besides showing the limiting nature of traditional stereotypes adding to the alienation Mina and Mariam experience, this binary differentiation also demonstrates the different forms Heimat can take. Najla and Salaa for example need the collective identity of their community that offers grouping possibilities ${ }^{33}$ and a sense of protection. In opposition to this need stands Mina's and Mariam's wish for freedom. Najla and Salaa accept the categorizing character of traditional gender roles and the associated hierarchical component positioning women in a place not even to men. Picturing such a lifestyle adds to Mariam's and Mina's feeling of being trapped and strengthens their wish to leave for a new - and free - Heimat.

Here, a closer look is taken on this new Heimat in question and the realization of it. At the base of this search stands the protagonists' need for liberation from a tight-fit community. Both women want to flee the restraints and marginalizations associated with their former surroundings. To discuss the different aspects and motivations for this search, the analysis is divided in two parts: One being in relation to Bloch's Heimat concept and the other one based on Gumbrecht's idea of Heimat.

The first describes Heimat as an unknown place and since Heimat contains a positive connotation, it will here be named the unknown paradise. Especially this abstract and enigmatic note of the concept makes it so desirable for Mariam and Mina, since it allows them to project all their dreams and wishes onto it. In fact, they add the opposite of their negative experiences to their idea of the new Heimat. By this, Heimat becomes in fact the other of everything they have known. This place is for them the Western society and the consumerist lifestyle associated with it. One of the characters of Vrouwland - Younes - gives a very symbolic description of this

\footnotetext{
31 Ibid., p. 160 .

32 Ibid., p. 107.

33 See V. Vordermayer, op. cit., p. 28.
} 
world in the beginning of the novel while watching TV advertising: "Colgate, voor een stralende glimlach, stralend zoals wij. Mooi en zonder gebreken. (...) Er is geen vuiligheid, geen ziekte, geen dood in onze wereld. Tast toe" ${ }^{34}$. This promise of a better life drives Mariam and Mina towards this world and leads them to radically opt for this new reality - for example by changing their name to better fit in - without even knowing the implications going with this decision.

At the end of both novels, the reader might ask himself/herself if the protagonists were - after all their efforts - able to find and make a home of this unknown paradise. As far as Mariam is concerned, the ending suggests a change in her radicality of choice. She is on a rather involuntarily trip to Morocco and stands on a graveyard. The last words of the novel read: "De wind stak op en trok aan de plastic zak die ze vasthield. Ze hield haar arm omhoog en liet los. De wind nam de zak dankbaar mee omhoog" ${ }^{35}$. A symbolic reading of this last paragraph can be that Mariam eventually lets go of her obsessive wish to be essentially part of a certain world and Heimat and to deny the one she is coming from. Her first journey as an adult to Morocco makes her aware of the ununified character of her Heimat, the impossibility to fight it and the utopian character of Heimat as a well-defined paradise. Eventually, Mariam has to accept her multi-layered identity and the complexity of Heimat that comes with it.

The end situation of De verstotene has a far more dramatic character. Mina finds herself pregnant from an almost stranger who rejects her and she struggles with depression due to her unprocessed trauma of being expelled by her own family. As a conclusion, the Western world does not offer the aspects that Mina needs so desperately to create her own vision of Heimat. Disillusioned, she decides to commit suicide. But when she is standing on her balcony, on the brink of jumping, Mina realizes the potential of having a baby. For Mina, Gumbrecht's definition of Heimat is very applicable. Her search for Heimat is strongly linked to the wish for finding people to love and who would love her back. In other words, the psychological dimension of Heimat is more dominant in Mina's own world of thought, while the topological dimension of the concept cannot be overlooked in the case of Mariam, who has been to Morocco - her fatherland - on several occasions and lives a very concrete in-betweenness between Belgium and Morocco. But for Mina, rather than finding a place, she wants to feel home in a sense of shared love. In this logic, standing on the wall of her balcony, she realizes that a child could mean the materialization of her wishes and the final goal of her search for Heimat: "Misschien moet ik niet sterven en zal het leven anders zijn, omdat ik nu eindelijk iemand heb voor wie ik moet zorgen, voor wie ik alles moet doen. (...) ik heb nu iets om voor te leven (...), want ik ben niet meer alleen" ${ }^{36}$. But with this ultimate aim in reach, she loses balance and falls down. This is the end of the novel and the reader is left with his/her own interpretation of it. One might suggest that the end mirrors in its radicality the uncompromising choice Mina took in order to find a new home. Both end situations can be read as a plea for the complexity of Heimat and identity and the needed acceptance of it.

\footnotetext{
34 R. LAMrabeT, op. cit., p. 15.

35 Ibid., p. 228.

36 N. El Bezaz, op. cit., p. 244.
} 
One goal of the article is to give the reader an idea of the broader context in which this text is embedded. In order to do so, the main pillars of the doctoral study - of which this article presents one of the first steps - are explained in the introductory part. This approach helps to make the link between the complex concept of Heimat and the mechanism of categorization. While reading the literary analysis of Heimat, one discovers the formability and ununiformed nature of the concept that implicitly hint at the mechanism of categorization and its disputable application. Another connection with the broader picture that this paper encourages is the nexus between Heimat and identity (quest). This concept is closely linked to the idea of Heimat, which can be considered to be a part of the wider notion of identity. This first approach thus sets the tone for a larger research project and offers a starting point for more extensive analysis.

Furthermore, the article aims at studying and highlighting the concept of Heimat in general and its multi-layered dimension in particular - especially for individuals having a migration background - in the field of literature. This complexity is reflected by the multitude of definitions associated with the term and illustrated by the analysis of Vrouwland and De verstotene - novels revolving around protagonists coming from immigratory communities. The study concentrates particularly on aspects such as religion, gender, colour of skin and ethnicity - all related to concrete interpersonal relations in the novels -, which are able to exert influence on one's shaping of an individual Heimat. The inquiry into the influences of these elements on the characters Mina and Mariam - and especially on their personal notion of Heimat - underlines the complex nature of this concept. The comparative analysis of Mina's and Mariam's personal development and in particular the literary examination of the two novels' closing scenes provides another clear example of the multi-layered nature of Heimat. While Mina's individual Heimat is dominated by the psychological dimension of the concept, Mariam lives in a concrete in-betweenness between Belgium and Morocco and thus experiences a Heimat based more on the topological dimension.

When looking for factors that form the individual Heimat of a person, the gender aspect turns out to be especially revealing in its impact on characters' sense of freedom as well as self-acceptance. In this context, the analysis of gender aspects of Heimat contains first elements that could help answering the key question of the doctoral thesis about so-called feminine concepts. The search of Heimat in Vrouwland and De verstotene clearly shows the complexity as well as the highly individual meaning of the term and accents the immense diversity of factors responsible for the shaping of one's Heimat - surpassing binary categorisations in Heimat and non-Heimat. 